\title{
How Successful is Supplemental Intraseptal and Buccal Infiltration Anaesthesia in the Mandibular Molars of Patients Undergoing Root Canal Treatment or Tooth Extraction?
}

\author{
Giath Gazal', Rayan Bahabri², Albraa B. Alolayan', Mahmod Alkayyal', Rahaf Al-Ghamdi ${ }^{3}$, \\ Ruwaa Salamah ${ }^{3}$ \\ ${ }^{1}$ Department of Oral and Maxillofacial, College of Dentistry, Taibah University, Medina, Kingdom of Saudi Arabia. \\ ${ }^{2}$ Department of Restorative Dental Sciences, Division of Endodontics, College of Dentistry, Taibah University, Medina, \\ Kingdom of Saudi Arabia. \\ ${ }^{3}$ College of Dentistry, Taibah University, Medina, Kingdom of Saudi Arabia.
}

\author{
Corresponding Author: \\ Giath Gazal \\ Department of Oral and Maxillofacial \\ College of Dentistry, Taibah University \\ Al Munawara, P.O. 2898, Zip Code: 41311, Al Madina \\ Saudi Arabia \\ Phone: +966 532158697 \\ Fax: +966 5432168699 \\ E-mail: gazal73@yahoo.co.uk
}

\begin{abstract}
Objectives: To investigate the success rate of supplemental intraseptal and buccal infiltration anaesthesia in mandibular molars undergoing endodontic therapy/extraction when the inferior alveolar nerve block has failed.

Material and Methods: A prospective clinical trial including 200 patients undergoing lower molar root canal treatment/teeth extraction was conducted. Only 80 patients of the participants who had profound lower lip anaesthesia after the administration of inferior alveolar nerve block (IANB) were in pain within treatment. Patients experiencing moderate to severe pain upon using elevators, forceps, bur, or endodontic file were randomly allocated to the $2 \%$ lidocaine intraseptal injection and $4 \%$ articaine buccal infiltration groups. Level of pain was assessed every 2 to $10 \mathrm{~min}$ on standard $100 \mathrm{~mm}$ visual analogue scales. Results: Overall, $55(69 \%)$ of patients who were given either intraseptal injection of $2 \%$ lidocaine or buccal infiltration of $4 \%$ articaine had successful anaesthesia of lower molar teeth within 10 min. However, 25 (31\%) of participating patients in the buccal infiltration and the intraseptal groups had failed anaesthesia within the study duration (10 min), and they received additional local anaesthetic. IANBs were more painful than buccal and intraseptal injections. However, buccal articaine injections were significantly more comfortable than intraseptal lidocaine injections $(\mathrm{P}>0.001)$.

Conclusions: Supplemental intraseptal injection of $2 \%$ lidocaine and buccal infiltration of $4 \%$ articaine achieved profound pulpal anaesthesia in $69 \%$ of patients when the inferior alveolar nerve block failed. Recommendations can be given to dental practitioners to use infiltration of $4 \%$ articaine in conjunction with intraseptal injection of $2 \%$ lidocaine to anaesthetize the lower molar teeth when inferior alveolar nerve block fails.
\end{abstract}

Keywords: dental anesthesia; endodontics; inferior alveolar nerve; local anesthetics; mandible; teeth extraction.

Accepted for publication: 17 March 2020

To cite this article:

Gazal G, Bahabri R, Alolayan AB, Alkayyal M, Al-Ghamdi R, Salamah R.

How Successful is Supplemental Intraseptal and Buccal Infiltration Anaesthesia in the Mandibular Molars of Patients Undergoing Root Canal Treatment or Tooth Extraction?

J Oral Maxillofac Res 2020;11(1):e5

URL: http://www.ejomr.org/JOMR/archives/2020/1/e5/v11n1e5.pdf

doi: $10.5037 /$ jomr.2020.11105 


\section{INTRODUCTION}

Difficulties in achieving anaesthesia of the mandibular molar teeth remain unresolved [1]. Failure of anaesthesia in the lower teeth is still occurring despite the availability of successful methods of local anaesthesia and the presence of clinical signs indicating the effectiveness of the injection [2]. Articaine has gradually gained a wide popularity amongst all the local anaesthetics because of its chemical structures. It has the capacity to rapidly diffuse within the bone and anaesthetize the mandibular teeth [3-5]. In literature, many research articles have examined the potency of $4 \%$ articaine buccal infiltration as a strong alternative to the conventional inferior alveolar nerve block (IANB) [1-5]. Buccal infiltration with articaine increased the success rate of IANBs in mandibular first molars with symptomatic pulpitis [4]. However, a recent mini systematic review suggested that the use of $4 \%$ articaine for IANBs may become the primary anaesthetic of choice [ $\underline{5}$ ]. This can only be possible if clinical evidence becomes available, confirming that there is no risk of nerve damage when articaine is administered for IANBs in patients undergoing local anaesthesia for dental treatment [6]. Buccal infiltration techniques for the mandibular teeth have been reported to have different rates of success, ranging from 24 to $84 \%$ [7]]. Simpson et al. [] reported that $4 \%$ articaine buccal infiltration after the failure of IANB in the mandibular teeth with irreversible pulpitis achieved a success rate of 24 to $38 \%$. However, an anaesthesia success rate of $84 \%$ was obtained by giving an extra buccal infiltration with articaine following the failure of IANB [9] Intraseptal injection technique using $2 \%$ lidocaine achieved an anaesthetic success rate of $30 \%$ for the mandibular first molar [10]. Recent study by Dianat et al. [11] revealed that the administration of an additional articaine intraseptal injection to IANB in mandibular molars of patients with symptomatic irreversible pulpitis achieved a success rate of $80 \%$. However, some complications included severe painful sensation during injection, and the degree of the porosity of the cortical plate of mandible bone limited the use of this method [12-16]. Therefore, dental practitioners worldwide are in search of alternative IANB methods to successfully achieve anaesthesia of the lower mandibular teeth $[1, \underline{12}]$. Administration of IANBs is an unfavourable procedure for many practitioners because the technique requires a welltrained clinician. It is also associated with high failure rate, addition to complications such as muscle trismus, transient hemifacial paralysis, haematoma formation, and needle breakage $[13,14]$. Moreover, re-injection of IANBs into the same location can be one of the options used to overcome the failure of anaesthesia caused by the first injection, but it only achieves $32 \%$ success rate [4]. However, re-injection for the second time can cause moderate to severe pain resulting from re-insertion of the needle in the traumatized soft tissue, and haemorrhage formation inside the medial pterygoid muscle and fibrosis which lead to trismus that occurs 2 to 5 days after the IANB injection [9]. In light of these facts, this study aimed to identify a new supplementary means of anaesthesia induction which might be used as an alternative technique for the mandibular molar teeth during root canal treatment or extraction when conventional inferior alveolar nerve block fails.

\section{MATERIAL AND METHODS}

This clinical trial was conducted from July 17, 2018, to April 17, 2019 in the Oral and Maxillofacial Department at Taibah Dental College. Healthy adult patients from the Taibah Dental College, AlMadinah Al-Munawwarah, were recruited in this study. Consort flow diagram was used to describe the study design and groups (Figure 1). All patients included in this study met the following criteria: 18 - 65 years of age, in good health (American Society of Anaesthesiologists classification I or II), they have one tooth for either dental extraction or endodontic treatment. Patients who are allergic to local anaesthetics, having significant medical conditions (classification III or greater according to American Society of Anesthesiologists [17]), taking depressant/analgesic medications 6 hours before treatment, pregnant, or unable to give informed consent were excluded. Ethics Committee of Taibah Dental College approved the study on May 3, 2018 under a protocol registration number: IRB \#00010037, and written informed consent was obtained from each patient. To qualify for the study, patient must have lower molar tooth that has been diagnosed for either extraction or endodontic treatment. After obtaining informed consent, patients were administered IANB and dental extraction/ endodontic treatment were initiated immediately after profound lower lip numbness was felt. During the extraction process/endodontic treatment, if the patient complained of pain, the procedure was discontinued and the patient was asked to rate his initial pain on a $170 \mathrm{~mm}$ Heft-Parker visual analogue scale (VAS; Figure 2) [18]. The VAS was divided into four categories as described previously $[\underline{8}, \underline{19}, \underline{20}]$ 


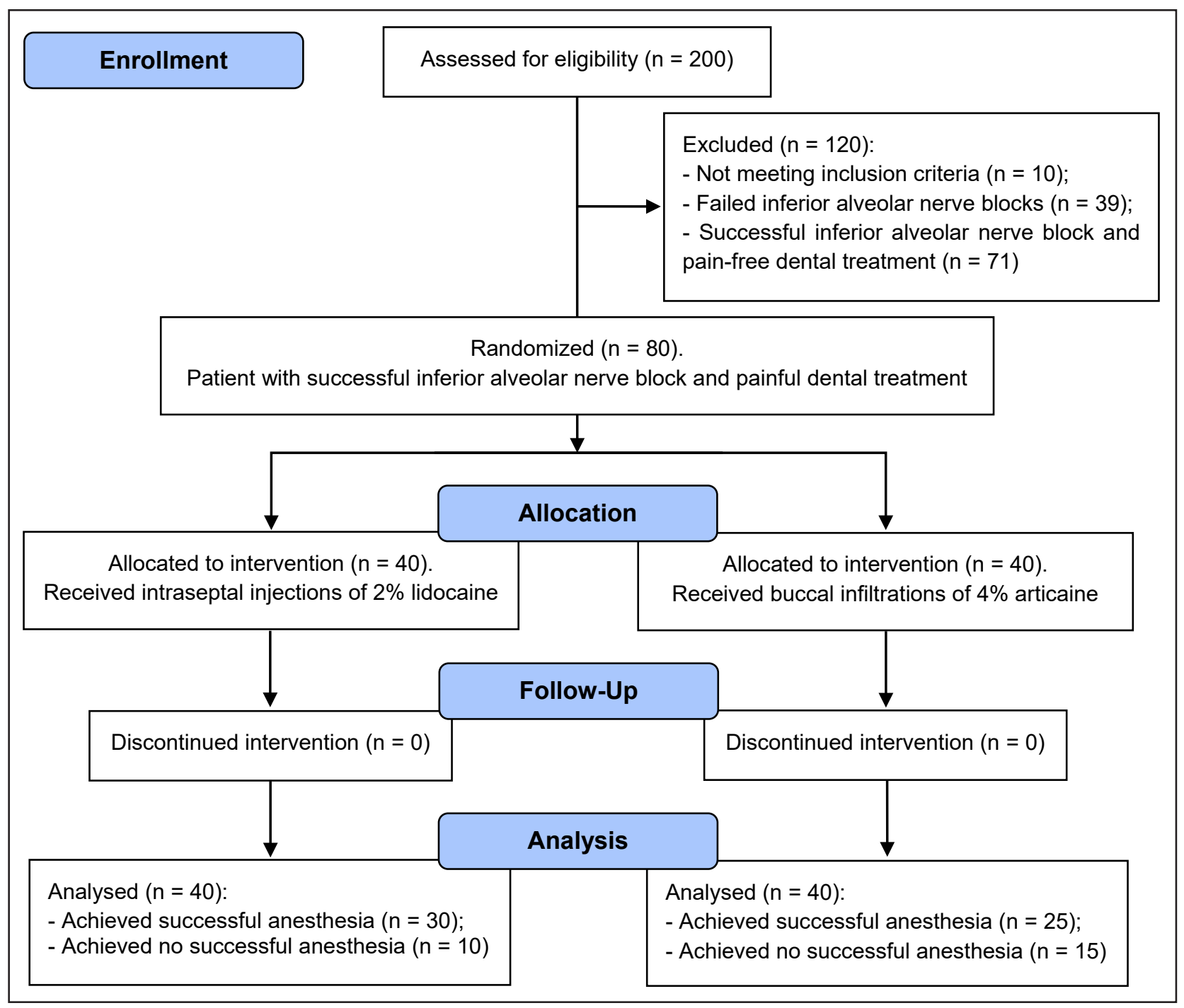

Figure 1. Consort flow chart with description of study design and study groups.

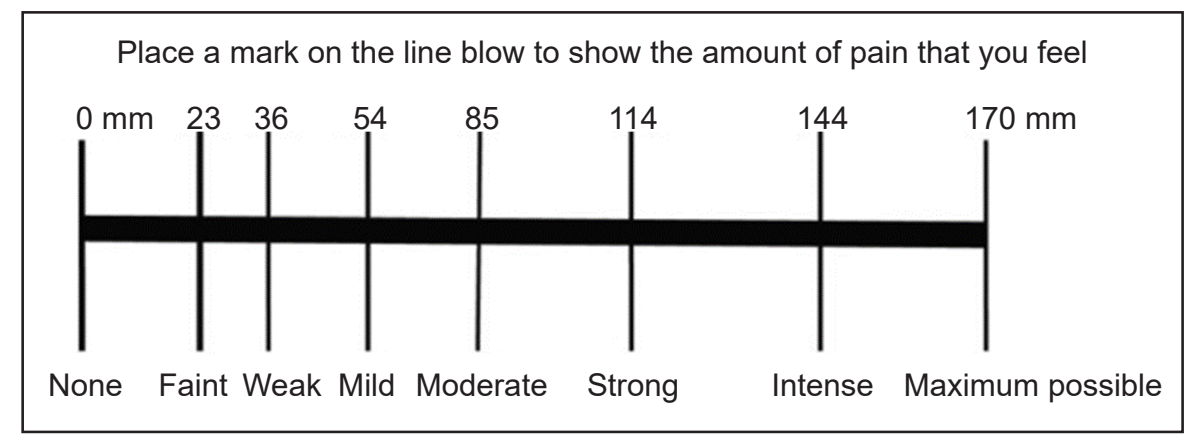

Figure 2. Pain scores measured by $170 \mathrm{~mm}$ Heft-Parker visual analogue scale.

and were defined as follows:

1. No pain corresponded to $0 \mathrm{~mm}$;

2. Mild pain was defined as $>0$ and $\leq 54 \mathrm{~mm}$ and included the descriptors of faint, weak, and mild pain;

3. Moderate pain was defined as $>54$ and $<114 \mathrm{~mm}$;

4. Severe pain was defined as $\geq 114 \mathrm{~mm}$ and included the descriptors of strong, intense, and maximum possible.
Every patient in this study was given one cartridge of $2 \%$ lidocaine with $1: 100,000$ epinephrine, using a conventional IANB technique and syringe (A. Titan Instruments, Inc.; Orchard Park, New York, USA) with a 27 -gauge, $30 \mathrm{~mm}$ long needle (C-K Ject [27 G] 0.4 x $30 \mathrm{~mm}$, Korea). Patient's lower lip was checked every 2 minutes to record the onset time for profoundness of anesthesia. Study giving time for achieving deep lower lip anaesthesia was 
10 min. Patients who failed to have profound lower lip numbness were discontinued from participation in the study and their dental treatment was carried out after giving them extra local anaesthesia. For patients who achieved profound lower lip numbness and scheduled for lower molars extraction, $0.9 \mathrm{~mL}$ $2 \%$ lidocaine with $1: 100,000$ epinephrine was injected for long buccal nerve anaesthesia. During the extraction procedure/endodontic treatment, if the patient suffered from pain, the dental treatment was stopped, and the patient was asked to report his level of pain by using the Heft-Parker VAS. Patients who reported mild pain, extraction/endodontic treatment were continued. However, patients who were reported moderate to severe pain $(55 \mathrm{~mm}$ or higher on the VAS), the attached opaque envelope was opened and the slip of paper was examined by an independent dental surgeon who administered either intraseptal or buccal infiltration injections. The success of the IANB was defined as the ability to perform the tooth extraction or root canal treatment with no or mild pain (VAS score of 0 or $\leq 54 \mathrm{~mm}$, respectively). All patients experiencing moderate to severe pain upon using elevators, forceps, bur, or file were given either a supplemental intraseptal injection of $2 \%$ lidocaine or buccal infiltration of $4 \%$ articaine. Intraseptal injections were administered into the mesial and distal aspect of the involved tooth using $0.8 \mathrm{~mL} 2 \%$ lidocaine with $1: 100,000$ epinephrine. A 27 -gauge, $21 \mathrm{~mm}$ short needle (C-K Ject [27 G] $0.4 \times 21 \mathrm{~mm}$, Korea) was inserted into the target region, which was located 2 to $3 \mathrm{~mm}$ apical to the apex of the papillary triangle. The needle was introduced into the soft tissue and advanced until contact with the bone was made. Pressure was applied to the syringe to drive the tip slightly deeper ( 1 to $2 \mathrm{~mm}$ ) into the interdental septum. Thereafter, anaesthetic solution $(0.4 \mathrm{ml})$ was deposited over a minimum of 20 seconds time. Buccal infiltrations of $4 \%$ articaine (Septanest SP articaine hydrochloride 4\% with $1: 100,000$ epinephrine - Septodont, France) were administered in the mucobuccal fold of the subject's tooth over 60 seconds. Dental extraction was resumed immediately after completion of the intraseptal injection or buccal infiltration if the patient reported no or mild pain. The patient's pain level was assessed every 2 to 10 minutes. After $10 \mathrm{~min}$ if the patient was still feeling moderate to severe pain, treatment was again discontinued, and the extraction was considered a failure. The painful sensation associated with the injections was recorded by the patients following IANB, intraseptal injection, and buccal infiltration anaesthesia on standard $100 \mathrm{~mm}$ VAS, tagged at the endpoints with "no pain" $(0 \mathrm{~mm})$ and "unbearable pain" (100 mm).

\section{Statistical analysis}

Based on a study by Webster et al. [2] 73 patients were reported to have $84 \%$ power to detect a difference in anaesthetic success rate of $30 \%$ in a continuous outcome measure assuming a significance level of $5 \%$ and a correlation of 0.5 between responses from the same subject. Therefore, a sample size of 80 patients would be enough to detect a confidence interval at half width of 0.09 with a certainty of $90 \%$. Data was analysed by using statistical software package SPSS (SPSS 18.0, SPSS Inc., Chicago, USA). Onset time of anaesthesia and injection discomfort was calculated using Student's t-test as mean and standard deviation (M [SD]). Statistical significance level was defined at $\mathrm{P}=0.05$.

\section{RESULTS}

Of 200 patients recruited in this study, 10 patients were dropped out of the study because they met the exclusion criteria (6 patients had surgical extraction and 4 patients fainted after the administration of LA). Moreover, $39(20.5 \%)$ patients with failure of IANB and $71(37.5 \%)$ patients with successful IANB and pain-free dental treatment (tooth extraction/root canal treatment of reversible/irreversible pulpitis) were excluded consequently based on the study protocol and official clearances. The final sample size included 80 patients: $56(70) \%$ of participants were male and $24(30) \%$ were female. The ages of patients ranged between 18 to 70 years, with mean age of 36 (13) years.

Eighty-eight percent of participants were diagnosed with grossly decayed teeth, 5\% with dental abscess, and $7 \%$ with periodontal disease.

\section{Anaesthetic success}

Overall, $55(69 \%)$ patients in this study achieved successful anaesthesia in the lower molar teeth after suplemental intraseptal injection of $2 \%$ lidocaine and buccal infiltration of $4 \%$ articaine within 10 min and consequently had pain-free procedures. However, there were $15(19 \%)$ patients in the buccal infiltration group and $10(12 \%)$ patients did not achieve anaesthetic success within the study duration $(10 \mathrm{~min})$ and an additional local anaesthetic was administered. Table 1 summarizes the overall outcome of the anaesthetic success for the lower molar teeth in the 80 patients who participated in the study. 
Table 1. The number of times recorded for successful anaesthesia in the lower molar teeth at specified intervals after suplamental lidocaine intraseptal injections and articaine buccal infiltrations in 80 adult patients

\begin{tabular}{l|c|c|c|c|c|c|c|c|c|c}
\hline $\begin{array}{c}\text { Anaesthetic success } \\
\text { by time interval }\end{array}$ & $\begin{array}{c}\mathbf{1} \\
\mathbf{m i n}\end{array}$ & $\begin{array}{c}\mathbf{2} \\
\mathbf{m i n}\end{array}$ & $\begin{array}{c}\mathbf{3} \\
\mathbf{m i n}\end{array}$ & $\begin{array}{c}\mathbf{4} \\
\mathbf{m i n}\end{array}$ & $\begin{array}{c}\mathbf{5} \\
\mathbf{m i n}\end{array}$ & $\begin{array}{c}\mathbf{6} \\
\mathbf{m i n}\end{array}$ & $\begin{array}{c}\mathbf{7} \\
\mathbf{m i n}\end{array}$ & $\begin{array}{c}\mathbf{8} \\
\mathbf{m i n}\end{array}$ & $\begin{array}{c}>\mathbf{1 0} \\
\mathbf{m i n}\end{array}$ & Total \\
\hline Buccal articaine group & 3 & 3 & 5 & 1 & 7 & 2 & 2 & 2 & 15 & 40 \\
\hline Intraseptal lidocaine group & 1 & 10 & 7 & 1 & 6 & 1 & 2 & 2 & 10 & 40 \\
\hline
\end{tabular}

Onset time of suplemental anaesthesia for mandibular molar teeth in the buccal articaine and intraseptal lidocaine groups

In this study, the time required to start removing the teeth that did not show any sign of pain after giving the local anaesthetic ranged from 1 to 16 min. Mean onset time of anaesthesia for patients in the buccal articaine and intraseptal lidocaine groups were, respectively, 4.2 (2.12) and 3.73 (1.98) min (Table 2). Analysis by Student's t-test revealed that there were no significant differences in the mean onset time of anaesthesia for dental treatment of lower molar teeth in patients who received either buccal articaine or intraseptal lidocaine injections $(\mathrm{P}=0.403)$. Clinically, patients in the intraseptal injection group recorded faster onset time of anaesthesia than those who were in the buccal articaine group.

\section{Onset time of suplemental anaesthesia for tooth extraction and endodontic treatment groups}

Thirty-six patients in this study underwent teeth extraction and nineteen patients underwent endodontic treatment. Mean onset time of anaesthesia for patients in dental extraction and endodontic treatment groups were 3.86 (1.97) and 4.11 (2.21) min respectively (Table 2). There were no significant differences in the mean onset time of anaesthesia for patients in dental extraction and endodontic treatment groups $(\mathrm{P}=0.677)$ (Table 2). Clinically, patients with teeth extraction had a faster onset time of anaesthesia than patients with endodontic treatment.

\section{Injection discomfort}

Level of discomfort associated with the injection's technique was recorded by the patients on standard $100 \mathrm{~mm}$ VAS, tagged at the endpoints with "no pain" $(0 \mathrm{~mm})$ and "unbearable pain" (100 $\mathrm{mm})$. The range of pain injection scores of patients in the study was from 0 to 100 . The mean pain scores during needle insertion of IANB, intraseptal, and buccal infiltration injections were 41 (20.5), 16 (19.8), and 9 (13.4) $\mathrm{mm}$, respectively. There were significant differences between the mean pain scores for patients in the post IANB, post intraseptal lidocaine, and post buccal articaine injection groups $(\mathrm{P}>0.001)$ (Table 3, Figure 3). IANBs were more painful than buccal and intraseptal injections. However, buccal articaine injections were significantly more comfortable than intraseptal lidocaine injections $(\mathrm{P}>0.001)$.

\section{DISCUSSION}

The results of this study showed that the articaine buccal infiltration and lidocaine intraseptal injection techniques can be used as alternative methods for overcoming failure of anaesthesia in the mandibular teeth following IANB. In recent years, there was a strong belief in the potency of articaine for achieving the highest rate of success of anaesthesia in the mandibular teeth. Articaine is a local anaesthetic

Table 2. Comparisons between mean onset time of anaesthesia for patients in buccal articaine, intraseptal lidocaine, dental extraction, and endodontic treatment groups

\begin{tabular}{|c|c|c|c|c|c|c|}
\hline \multicolumn{2}{|r|}{ Groups } & \multicolumn{2}{|c|}{$\begin{array}{c}\text { Number of } \\
\text { patients }\end{array}$} & \multirow{2}{*}{$\begin{array}{c}\begin{array}{c}\text { Mean (SD), } \\
\text { min }\end{array} \\
4.2(2.12) \\
\end{array}$} & \multirow{3}{*}{$\begin{array}{c}\begin{array}{c}\text { t-test } \\
(\mathbf{d f}=\mathbf{5 3})\end{array} \\
0.842\end{array}$} & \multirow{3}{*}{$\begin{array}{c}\text { P-value } \\
0.403^{\mathrm{a}}\end{array}$} \\
\hline \multirow{4}{*}{$\begin{array}{l}\text { Onset time of } \\
\text { action }\end{array}$} & Buccal articaine regimen & 25 & \multirow{2}{*}{55} & & & \\
\hline & Intraseptal lidocaine regimen & 30 & & $3.73(1.98)$ & & \\
\hline & Dental extraction & 36 & \multirow{2}{*}{55} & $3.86(1.97)$ & \multirow{2}{*}{-0.419} & \multirow{2}{*}{$0.677^{\mathrm{b}}$} \\
\hline & Endodontic treatment & 19 & & $4.11(2.21)$ & & \\
\hline
\end{tabular}

${ }^{\text {aN }}$ o significant difference in means of anaesthesia onset time between buccal articaine and intraseptal lidocaine regimens ( $\mathrm{P}=0.403$, Student's t-test).

${ }^{b}$ No significant difference in means of anaesthesia onset time between dental extraction and endodontic treatment $(\mathrm{P}=0.677$, Student's t-test $)$.

$\mathrm{SD}=$ standard deviation 
Table 3. Comparisons between the mean of pain scores post inferior alveolar nerve block (IANB), articaine buccal infiltration, and lidocaine intraseptal injection groups

\begin{tabular}{|c|c|c|c|c|}
\hline Pain score groups & $\begin{array}{c}\text { Number of } \\
\text { patients }\end{array}$ & $\begin{array}{l}\text { Mean (SD), } \\
\min \end{array}$ & t-test & P-value ${ }^{a}$ \\
\hline Post IANB & 80 & $41(20.5)$ & \multirow{3}{*}{17.85} & \multirow{3}{*}{$<0.001$} \\
\hline Post intraseptal injection & 40 & $16(19.8)$ & & \\
\hline Post buccal infiltration & 40 & $9(13.4)$ & & \\
\hline Post intraseptal injection & 40 & $16(19.8)$ & \multirow{2}{*}{5.08} & \multirow{2}{*}{$<0.001$} \\
\hline Post buccal infiltration & 40 & $9(13.4)$ & & \\
\hline
\end{tabular}

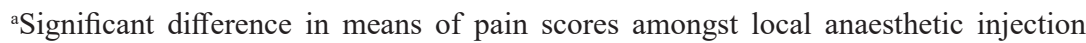
techniques $(\mathrm{P}<0.001$, Student's t-test).

$\mathrm{SD}=$ standard deviation

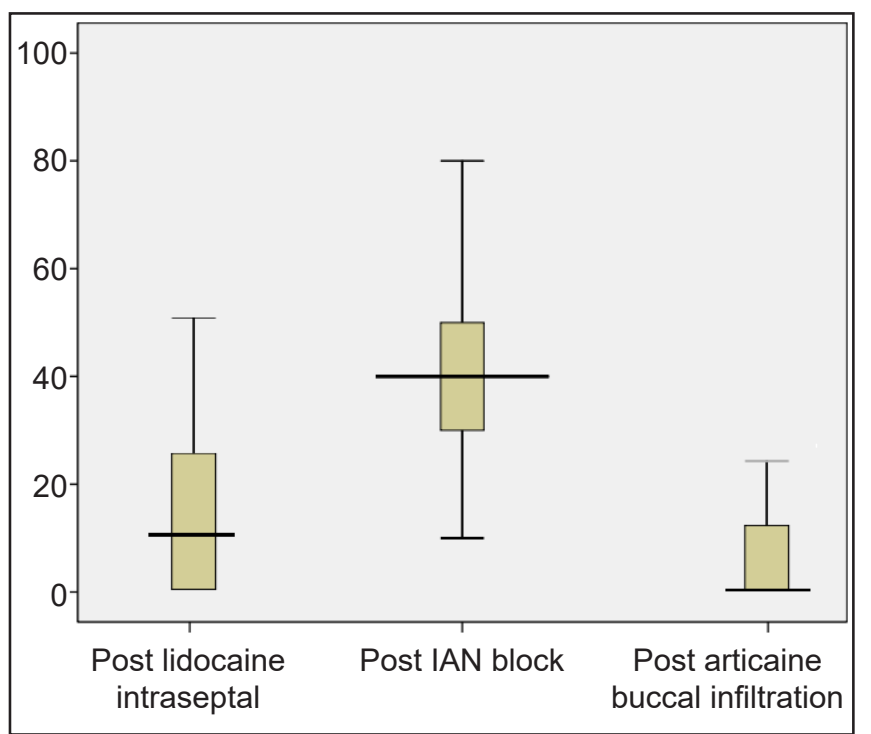

Figure 3. Mean pain scores for patients of post inferior alveolar nerve (IAN) block, post lidocaine intraseptal injections and post articaine buccal infiltration groups.

agent similar to lidocaine [20-22]. The chemical structure of articaine contains a thiophene ring which has greater lipid-solubility than the benzene ring found in lidocaine [14,23-24]. This implies that the articaine molecule has a strong potency for diffusion through soft and hard tissues. Therefore, a greater volume of local anaesthetic dose can enter the target neurons and cause a rapid onset of action and profound anaesthesia [12-15]. Based on this, it was thought that the infiltration of articaine around the lower molar teeth would have similar effectiveness as the IANB. However, the limitation that reduced the success of articaine infiltration injection when used to anaesthetize the lower molar teeth was the thickness of the buccal cortical plate of the mandibular bone [25-26]. Articaine buccal infiltration can be a successful injection for the anaesthesia of the mandibular teeth, on condition that the thickness of the buccal cortical plate of mandibular bone is $\leq 3 \mathrm{~mm}$. Thus, one explanation for the failure of articaine buccal infiltration in this study could be the thickness of buccal cortical plate, which would have been more than $3 \mathrm{~mm}$. Conversely, intraseptal injection technique was clinically more successful than articaine infiltration technique for the anaesthesia of lower molar teeth, but the differences were not statistically significant. One possible explanation for the superiority of intraseptal technique over articaine buccal infiltration could be the insertion of the bevel of the short needle in the intraseptal bone, which resulted in reduced thickness of the buccal cortical plate and consequently a shorter distance of diffusion [27-31]. Although this study showed a reasonable success rate of buccal and intraseptal injection techniques for the mandible molar teeth, a few patients reported failure of anaesthesia and required additional doses. Two types of dental procedures were performed in this study: dental extraction and endodontic treatment. It was noticed that the speed of the anaesthetic action was faster in the subject's teeth for extraction than in the teeth for endodontic treatment. Therefore, the condition of the tooth might have influenced the success rate of anaesthesia [3235]. Patients with reversible/irreversible pulpitis attended for endodontic treatment usually experienced a delay or failure of anaesthesia. The first potential cause might be the inflammation of tooth pulp (pulpal hyperaemia) $[15,34]$. Pulpal hyperaemia causes an overactive response to pain (hyperalgesia). The tooth becomes more sensitive to pain owing to changes in the nerve pathways $[16,35]$. The second potential cause is pulpal tissue acidosis. In the presence of infection and inflammation (acidic PH), local anaesthetics (NR3-HCL) become inactive and fail to liberate the free bases (NR3) of the anaesthetic salts from its acid (HCL) and induce anaesthesia $[14,20,36]$. Therefore, acute irreversible/reversible pulpitis works as a restraint preventing the local anaesthetic from exerting its action.

Patients in this study reported that the IANB 
injections were more painful than the buccal and intraseptal injections. However, discomfort from the buccal infiltration injections was less than that from the intraseptal injections. IANB techniques require insertion of a needle through the periosteum, hitting the mandible bone, withdrawing the needle back to a distance of $2 \mathrm{~mm}$, and then deposition of the local anaesthetic solution around the mandible foramen. This procedure is painful for two reasons. One reason is the perforation of the periosteum, which is highly vascularized and innervated $[\underline{13-14}, \underline{25}]$. Another reason is the bending of the needle tip (fishhook) as a result of hitting the mandible bone recklessly $[12,15,27]$. Fishhook needle can cause tearing of the soft tissue and IAN upon its removal $[\underline{11}, \underline{14}, \underline{29}, \underline{30}]$. In the buccal injection technique, deposition of local anaesthetic solutions is above the periosteum [21]. This implies that the painful sensations associated with such an injection are only generated from the needle insertion through the mucosa, along with the building-up of pressure from the injectable anaesthetic solution [31-33]. In the intraseptal injections, the painful sensations are aroused from both the penetration of the periosteum and the building-up of pressure from the solution under the tightly adhered

\section{CONCLUSIONS}

Supplemental intraseptal injection of $2 \%$ lidocaine and buccal infiltration of $4 \%$ articaine achieved profound pulpal anaesthesia in $69 \%$ of patients when the inferior alveolar nerve block failed. Clinically, intraseptal anaesthesia was slightly faster and more effective than the buccal infiltration technique. Recommendations can be given to dental practitioners to use buccal infiltration of $4 \%$ articaine in conjunction with intraseptal injection of $2 \%$ lidocaine to anaesthetize the lower molar teeth when inferior alveolar nerve block fails.

\section{ACKNOWLEDGMENTS AND DISCLOSURE STATEMENTS}

We thank the oral and maxillofacial and operative departments in Taibah Dental College for their cooperation and help in the successful completion of this research. mucosa of the intraseptal areas $[11,24,35,37]$.

\section{REFERENCES}

1. Gazal G. Overcoming the failure of anesthesia in the mandibular teeth. Saudi Med J. 2019 May;40(5):425. [Medline: 31056616] [PMC free article: 6535176] [doi: 10.15537/smj.2019.5.24078]

2. Webster S Jr, Drum M, Reader A, Fowler S, Nusstein J, Beck M. How Effective Is Supplemental Intraseptal Anesthesia in Patients with Symptomatic Irreversible Pulpitis? J Endod. 2016 Oct;42(10):1453-7. [Medline: 27663614] [doi: 10.1016/j.joen.2016.07.002]

3. Majid OW, Muhammad ZA. Effectiveness of Articaine Buccal Infiltration Anesthesia for Mandibular Premolar Extraction: A Randomized, Double-Blind, Placebo-Controlled Clinical Trial. J Oral Maxillofac Surg. 2019 Sep;77(9):1784-1789. [Medline: 31028737 ] [doi: 10.1016/j.joms.2019.03.033]

4. Shahi S, Rahimi S, Yavari HR, Ghasemi N, Ahmadi F. Success Rate of 3 Injection Methods with Articaine for Mandibular First Molars with Symptomatic Irreversible Pulpitis: A CONSORT Randomized Double-blind Clinical Trial. J Endod. 2018 Oct;44(10):1462-1466. [Medline: 30174101] [doi: 10.1016/j.joen.2018.07.010]

5. Alzahrani F, Duggal MS, Munyombwe T, Tahmassebi JF. Anaesthetic efficacy of $4 \%$ articaine and $2 \%$ lidocaine for extraction and pulpotomy of mandibular primary molars: an equivalence parallel prospective randomized controlled trial. Int J Paediatr Dent. 2018 May;28(3):335-344. [Medline: 29573375] [doi: 10.1111/ipd.12361]

6. Stirrup P, Crean S. Does articaine, rather than lidocaine, increase the risk of nerve damage when administered for inferior alveolar nerve blocks in patients undergoing local anaesthesia for dental treatment? A mini systematic review of the literature. Br Dent J. 2019 Feb 8;226(3):213-223. [Medline: 30734772] [doi: 10.1038/sj.bdj.2019.98]

7. Lee CR, Yang HJ. Alternative techniques for failure of conventional inferior alveolar nerve block. J Dent Anesth Pain Med. 2019 Jun;19(3):125-134. [Medline: 31338418] [PMC free article: 6620537] [doi: 10.17245/jdapm.2019.19.3.125]

8. Simpson M, Drum M, Nusstein J, Reader A, Beck M. Effect of combination of preoperative ibuprofen/acetaminophen on the success of the inferior alveolar nerve block in patients with symptomatic irreversible pulpitis. $J$ Endod. 2011 May;37(5):593-7. [Medline: 21496654] [doi: 10.1016/j.joen.2011.02.015]

9. Kanaa MD, Whitworth JM, Meechan JG. A prospective randomized trial of different supplementary local anesthetic techniques after failure of inferior alveolar nerve block in patients with irreversible pulpitis in mandibular teeth. J Endod. 2012 Apr;38(4):421-5. [Medline: 22414822] [doi: 10.1016/j.joen.2011.12.006]

10. Bonar T, Nusstein J, Reader A, Drum M, Fowler S, Beck M. Anesthetic Efficacy of Articaine and Lidocaine in a Primary Intraseptal Injection: A Prospective, Randomized Double-Blind Study. Anesth Prog. 2017 Winter;64(4):203-211. [Medline: 29200372] [PMC free article: 5715303] [doi: 10.2344/anpr-64-04-10] 
11. Dianat O, Mozayeni MA, Layeghnejad MK, Shojaeian S. The efficacy of supplemental intraseptal and buccal infiltration anesthesia in mandibular molars of patients with symptomatic irreversible pulpitis. Clin Oral Investig. 2020 Mar;24(3):1281-1286. [Medline: 31302768] [doi: 10.1007/s00784-019-03006-8]

12. Gazal G, Fareed WM, Zafar MS. Role of intraseptal anesthesia for pain-free dental treatment. Saudi J Anaesth. 2016 Jan-Mar;10(1):81-6. [Medline: 26955316] [PMC free article: 4760049] [doi: 10.4103/1658-354X.169482]

13. Gazal G. Is prilocaine safe and potent enough for use in the oral surgery of medically compromised patients. Saudi Med J. 2019 Jan;40(1):97-100. [Medline: 30617388] [PMC free article: 6452603] [doi: 10.15537/smj.2019.1.23475]

14. Gazal G. Is Articaine More Potent than Mepivacaine for Use in Oral Surgery? J Oral Maxillofac Res. 2018 Sep 30;9(3):e5.

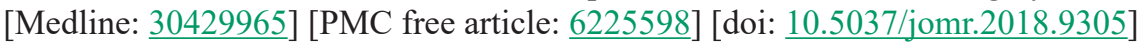

15. Alsharif A, Omar E, Alolayan AB, Bahabri R, Gazal G. 2\% lidocaine versus 3\% prilocaine for oral and maxillofacial surgery. Saudi J Anaesth. 2018 Oct-Dec;12(4):571-577. [Medline: 30429739] [PMC free article: 6180686] [doi: 10.4103/sja.SJA_259_18]

16. Gazal G, Alharbi AM, Al-Samadani KH, Kanaa MD. Articaine and mepivacaine buccal infiltration in securing mandibular first molar pulp anesthesia following mepivacaine inferior alveolar nerve block: A randomized, doubleblind crossover study. Saudi J Anaesth. 2015 Oct-Dec;9(4):397-403. [Medline: 26543456] [PMC free article: 4610083] [doi: 10.4103/1658-354X.159463]

17. Doyle DJ, Garmon EH. American Society of Anesthesiologists Classification (ASA Class). 2020 Feb 17. StatPearls [Internet]. Treasure Island (FL): StatPearls Publishing; 2020 Jan-. [Medline: 28722969]

18. Heft MW, Parker SR. An experimental basis for revising the graphic rating scale for pain. Pain. 1984 Jun;19(2):153-61. [Medline: 6462727] [doi: 10.1016/0304-3959(84)90835-2]

19. Stanley W, Drum M, Nusstein J, Reader A, Beck M. Effect of nitrous oxide on the efficacy of the inferior alveolar nerve block in patients with symptomatic irreversible pulpitis. J Endod. 2012 May;38(5):565-9. [Medline: 22515880] [doi: 10.1016/j.joen.2012.02.010]

20. Schellenberg J, Drum M, Reader A, Nusstein J, Fowler S, Beck M. Effect of Buffered 4\% Lidocaine on the Success of the Inferior Alveolar Nerve Block in Patients with Symptomatic Irreversible Pulpitis: A Prospective, Randomized, Double-blind Study. J Endod. 2015 Jun;41(6):791-6. [Medline: 25841959] [doi: 10.1016/j.joen.2015.02.022]

21. Aggarwal V, Singla M, Miglani S, Kohli S. Comparison of the anaesthetic efficacy of epinephrine concentrations (1:80 000 and $1: 200000)$ in 2\% lidocaine for inferior alveolar nerve block in patients with symptomatic irreversible pulpitis: a randomized, double-blind clinical trial. Int Endod J. 2014 Apr;47(4):373-9. [Medline: 23895176] [doi: $10.1111 /$ iej.12157]

22. Rogers BS, Botero TM, McDonald NJ, Gardner RJ, Peters MC. Efficacy of articaine versus lidocaine as a supplemental buccal infiltration in mandibular molars with irreversible pulpitis: a prospective, randomized, double-blind study. J Endod. 2014 Jun;40(6):753-8. [Medline: 24862701] [doi: 10.1016/j.joen.2013.12.022]

23. Singla M, Subbiya A, Aggarwal V, Vivekanandhan P, Yadav S, Yadav H, Venkatesh A, Geethapriya N, Sharma V. Comparison of the anaesthetic efficacy of different volumes of $4 \%$ articaine $(1.8$ and $3.6 \mathrm{~mL})$ as supplemental buccal infiltration after failed inferior alveolar nerve block. Int Endod J. 2015 Jan;48(1):103-8. [Medline: 24661235] [doi: $10.1111 /$ iej.12283]

24. Kanaa MD, Whitworth JM, Meechan JG. A prospective randomized trial of different supplementary local anesthetic techniques after failure of inferior alveolar nerve block in patients with irreversible pulpitis in mandibular teeth. J Endod. 2012 Apr;38(4):421-5. [Medline: 22414822] [doi: 10.1016/j.joen.2011.12.006]

25. Aggarwal V, Singla M, Subbiya A, Vivekanandhan P, Sharma V, Sharma R, Prakash V, Geethapriya N. Effect of Preoperative Pain on Inferior Alveolar Nerve Block. Anesth Prog. 2015 Winter;62(4):135-9. [Medline: 26650491] [PMC free article: $\underline{4675338}$ ] [doi: 10.2344/15-00019.1]

26. Fowler $\mathrm{S}$, Reader A. Is a volume of $3.6 \mathrm{~mL}$ better than $1.8 \mathrm{~mL}$ for inferior alveolar nerve blocks in patients with symptomatic irreversible pulpitis? J Endod. 2013 Aug;39(8):970-2. [Medline: 23880260] [doi: 10.1016/i.joen.2013.04.007]

27. Fowler S, Drum M, Reader A, Beck M. Anesthetic Success of an Inferior Alveolar Nerve Block and Supplemental Articaine Buccal Infiltration for Molars and Premolars in Patients with Symptomatic Irreversible Pulpitis. J Endod. 2016 Mar;42(3):390-2. [Medline: 26831048] [doi: 10.1016/i.joen.2015.12.025]

28. Monteiro MR, Groppo FC, Haiter-Neto F, Volpato MC, Almeida JF. 4\% articaine buccal infiltration versus 2\% lidocaine inferior alveolar nerve block for emergency root canal treatment in mandibular molars with irreversible pulpits: a randomized clinical study. Int Endod J. 2015 Feb;48(2):145-52. [Medline: 24702239] [doi: 10.1111/iej.12293]

29. Matthews R, Drum M, Reader A, Nusstein J, Beck M. Articaine for supplemental buccal mandibular infiltration anesthesia in patients with irreversible pulpitis when the inferior alveolar nerve block fails. J Endod. 2009 Mar;35(3):343-6. [Medline: 19249592] [doi: 10.1016/i.joen.2008.11.025]

30. Juodzbalys G, Wang HL, Sabalys G. Injury of the Inferior Alveolar Nerve during Implant Placement: a Literature Review. J Oral Maxillofac Res. 2011 Apr 1;2(1):e1. [Medline: 24421983] [PMC free article: 3886063] [doi: $10.5037 /$ jomr.2011.2101]

31. Nusstein J, Claffey E, Reader A, Beck M, Weaver J. Anesthetic effectiveness of the supplemental intraligamentary injection, administered with a computer-controlled local anesthetic delivery system, in patients with irreversible pulpitis. J Endod. 2005 May;31(5):354-8. [Medline: 15851928] [doi: 10.1097/01.DON.0000140565.88940.60] 
32. Cohen HP, Cha BY, Spångberg LS. Endodontic anesthesia in mandibular molars: a clinical study. J Endod. 1993 Jul;19(7):370-3. [Medline: 8245762] [doi: 10.1016/S0099-2399(06)81366-X]

33. Nusstein J, Reader A, Nist R, Beck M, Meyers WJ. Anesthetic efficacy of the supplemental intraosseous injection of $2 \%$ lidocaine with 1:100,000 epinephrine in irreversible pulpitis. J Endod. 1998 Jul;24(7):487-91. [doi: 10.1016/S0099-2399(98)80053-8]

34. Verma PK, Srivastava R, Ramesh KM. Anesthetic efficacy of X-tip intraosseous injection using 2\% lidocaine with 1:80,000 epinephrine in patients with irreversible pulpitis after inferior alveolar nerve block: A clinical study. J Conserv Dent. 2013 Mar;16(2):162-6. [Medline: 23716971] [PMC free article: 3659864] [doi: 10.4103/0972-0707.108202]

35. Nusstein J, Kennedy S, Reader A, Beck M, Weaver J. Anesthetic efficacy of the supplemental X-tip intraosseous injection in patients with irreversible pulpitis. J Endod. 2003 Nov;29(11):724-8. [Medline: 14651278] [doi: 10.1097/00004770-200311000-00010]

36. Berlin J, Nusstein J, Reader A, Beck M, Weaver J. Efficacy of articaine and lidocaine in a primary intraligamentary injection administered with a computer-controlled local anesthetic delivery system. Oral Surg Oral Med Oral Pathol Oral Radiol Endod. 2005 Mar;99(3):361-6. [Medline: 15716846] [doi: 10.1016/j.tripleo.2004.11.009]

37. Gazal G, Omar E, Fareed WM, Alsharif A, Bahabri R. Impact of maxillary teeth morphology on the failure rate of local anesthesia. Saudi J Anaesth. 2020 Jan-Mar;14(1):57-62. [Medline: 31998021] [PMC free article: 6970379] [doi: 10.4103/sja.SJA 542_19]

\section{To cite this article:}

Gazal G, Bahabri R, Alolayan AB, Alkayyal M, Al-Ghamdi R, Salamah R.

How Successful is Supplemental Intraseptal and Buccal Infiltration Anaesthesia in the Mandibular Molars of Patients Undergoing Root Canal Treatment or Tooth Extraction?

J Oral Maxillofac Res 2020;11(1):e5

URL: http://www.ejomr.org/JOMR/archives/2020/1/e5/v11n1e5.pdf

doi: $10.5037 /$ jomr.2020.11105

Copyright (C) Gazal G, Bahabri R, Alolayan AB, Alkayyal M, Al-Ghamdi R, Salamah R. Published in the JOURNAL OF ORAL \& MAXILLOFACIAL RESEARCH (http://www.ejomr.org), 31 March 2020.

This is an open-access article, first published in the JOURNAL OF ORAL \& MAXILLOFACIAL RESEARCH, distributed under the terms of the Creative Commons Attribution-Noncommercial-No Derivative Works 3.0 Unported License, which permits unrestricted non-commercial use, distribution, and reproduction in any medium, provided the original work and is properly cited. The copyright, license information and link to the original publication on (http://www.ejomr.org) must be included. 